\title{
Assessment of trace metal contamination in a historical freshwater canal (Buckingham Canal), Chennai, India
}

\author{
M.Jayaprakash $^{1}$, R.Nagarajan ${ }^{2 \dagger}$, P.M.Velmurugan ${ }^{1}$, J.Sathiyamoorthy ${ }^{1}$, \\ R.R.Krishnamurthy ${ }^{1}$ and B.Urban ${ }^{3}$ \\ ${ }^{1}$ Department of Applied Geology, \\ University of Madras, \\ Maraimalai Campus, \\ Chennai-25, India
}

${ }^{2}$ Department of Applied Geology,

School of Engineering and Science,

Curtin University,

CDT 250, Miri, 98009,

Sarawak, Malaysia

${ }^{3}$ Leuphana University of Lüneburg,

Faculty III,

Environmental Sciences and Engineering

Herbert-Meyer-Str. 7,

D 29556 Suderburg,

Germany

†Corresponding Author: R. Nagarajan

Department Applied Geology, School of Engineering and Science

Curtin University, CDT 250, Miri, 98009, Sarawak, Malaysia

Email: nagageochem@yahoo.com; nagarajan@curtin.edu.my

Tel: +60 165251245 ;

Fax: +60 85443837 


\begin{abstract}
The present study was done to assess the sources, and the major processes controlling the trace metal distribution in sediments of Buckingham Canal. Based on the observed geochemical variations, the sediments are grouped as South Buckingham Canal and North Buckingham Canal sediments (SBC and NBC respectively). SBC sediments show enrichment in $\mathrm{Fe}, \mathrm{Ti}, \mathrm{Mn}, \mathrm{Cr}, \mathrm{V}, \mathrm{Mo}$ and As concentrations, while NBC sediments show enrichment in $\mathrm{Sn}, \mathrm{Cu}, \mathrm{Pb}, \mathrm{Zn}$, $\mathrm{Ni}$ and Hg. The calculated Chemical Index of Alteration (CIA) and Chemical Index of Weathering (CIW) values for all the sediments are relatively higher than the North American Shale Composite (NASC) and Upper Continental Crust (UCC) but similar to Post Archaean Average Shale (PAAS), and suggest a source area with moderate weathering. Overall, SBC sediments are highly enriched in $\mathrm{Mo}, \mathrm{Zn}, \mathrm{Cu}$, and $\mathrm{Hg}$ (Igeo class 4-6), whereas NBC sediments are enriched in Sn, $\mathrm{Cu}, \mathrm{Zn}$ and $\mathrm{Hg}$ (Igeo class 4-6). $\mathrm{Cu}, \mathrm{Ni}$ and $\mathrm{Cr}$ show higher than ERM (EffectsRange Median) values and hence the biological adverse effect of these metals is $20 \%$; Zn, which accounts for $50 \%$, in the NBC sediments, has a more biological adverse effect than other metals found in these sediments. The calculated Geoaccumulation Index (Igeo), Enrichment Factor (EF) and Contamination Factor (CF) values indicate that $\mathrm{Mo}, \mathrm{Hg}, \mathrm{Sn}, \mathrm{Cu}$ and $\mathrm{Zn}$ are highly enriched in the Buckingham Canal sediments, suggesting the rapid urban and industrial development of Chennai Metropolitan City have negatively influenced on the surrounding aquatic ecosystem.
\end{abstract}

Key Words: Trace Metals; Canal sediments; Metal enrichment; Buckingham Canal; South India. 


\section{Introduction}

Exponential population growth and its related developmental activities (such as small-scale and large-scale industry, expansion of harbor, tourism and other commercial activities) often generate a huge amount of waste, which is often disposed into the natural ecosystems posing a serious health problem (Beiras et al. 2003). The rapid development of industries and population ( $\sim 8$ million) in the metropolitan city like Chennai has led to heavy pollution of the major waterways and adjoining coastal waters due to inadequate management of waste products (Ramesh et al. 2002). Moreover, the sediments act as carriers as well as sinks for contaminants in aquatic environment, where they are the largest repository and potential source of metal pollutants.

Trace elements, especially those called heavy metals, are among the most common environmental pollutants and their occurrence in waters and biota indicates the existence of natural or anthropogenic sources (Nabi Bidhendi et al. 2007). The sources of metals into the aquatic system can be natural (due to weathering of soils and rocks) or anthropogenic (due to industrial and urban wastes) (Klavins et al. 2000). Some trace elements (Cr, Co, Cu, Fe, Mn, Mo, V, Sr and $\mathrm{Zn}$ ), are essential for living organisms, whereas heavy metals are relatively toxic even at very low concentrations. Heavy metals participate in various biogeochemical mechanisms due to their mobility. They often affect ecosystems through bioaccumulation and biomagnification processes and are potentially toxic for the bionetwork (Sajwan et al. 2008). Hence, the analysis of sediments plays an important role in assessing metal contamination of aquatic environments (ElNemr et al. 2006). 
Most urban development in India still depends upon rivers for cleaning as well as disposal. It is therefore, very important to systematically study the status of river pollution in relation to various anthropogenic activities (Kaushik et al. 2009). The Buckingham Canal area is prone to both point and non-point sources of pollutants. Manali Industrial estate in the northern part of Chennai has been classified as red industries by Tamil Nadu Pollution Control and Central Pollution Control Board (Shanthi and Gajendran 2009) and considered as one of the problematic areas in the country. Considering the significant quantities of waste, both of industrial and domestic origin, being released into Buckingham Canal every year, it is of particular interest to evaluate the presence of trace metal pollution due to anthropogenic activities. Many studies have claimed that Buckingham Canal is one of the major sources for pollutants, as it carries pollutants from domestic and industrial waste of Chennai to Ennore creek, Pulicat lake and the Chennai coastal area (e.g. Jayaprakash et al. 2008, 2010; Kamala Kannan et al. 2006; Krishna and Govil 2008; Muthuraj and Jayaprakash 2008; Ramesh et al. 2002; Ravichandran 1987; Seshan et al. 2010). The present study was undertaken to identify the distribution patterns of major and trace metals in the sediments from Buckingham Canal in Chennai City. In addition, to highlight the geochemical behavior of the metals, multivariate statistical analyses were used to identify the associations among them.

\section{Materials and Methods}

Twenty two surface sediment samples were collected from a boat using Van Veen grab in June 2009. The sampling sites were selected on the basis of possible local and point sources. Samples were taken from the central part of the grab sampler to 
avoid any metallic contamination from the sampler itself and were frozen at $-4^{\circ} \mathrm{C}$ immediately onboard. The samples were separated following cone and quartering method and were powdered in an agate mortar. All the samples were analysed for major ( $\mathrm{Si}, \mathrm{Al}, \mathrm{Fe}$, and $\mathrm{Mn}$ ) and trace metals ( $\mathrm{S}, \mathrm{Cr}, \mathrm{Cu}, \mathrm{Pb}, \mathrm{Zn}, \mathrm{Co}, \mathrm{Ni}, \mathrm{Cd}, \mathrm{Sr}$, $\mathrm{Hg}, \mathrm{V}, \mathrm{As}$ ) using an X-ray fluorescence spectrometer (SpectroXepos-BenchtopRontgenfluorozenz-Spektrometer) equipped with an $\mathrm{Rh}$ tube at Leuphana University, Luneburg, Germany, as per the method described by Chen et al. (2001). The accuracy of the analytical method was established using internationally recognized standard reference materials (SRMs) viz., BCSS-1, and MESS-1. Based on these standards, the accuracy and precision of the analyses were within $1 \%$ for major elements and $5 \%$ for trace elements. To avoid errors due to contamination, high purity Merck chemicals were used, and all HDPE bottles were pre-cleaned with nitric acid and deionized water. Spearman (nonparametric) rank order correlations and cluster analysis were performed using SPSS program version 10.0 for Windows.

In order to quantify the degree of weathering, the Chemical Index of Alteration (CIA) was used (Nesbitt and Young 1982). This index was calculated using the molecular proportions as shown in the equation below:

$\mathrm{CIA}=\left[\mathrm{Al}_{2} \mathrm{O}_{3} /\left(\mathrm{Al}_{2} \mathrm{O}_{3}+\mathrm{CaO} *+\mathrm{Na}_{2} \mathrm{O}+\mathrm{K}_{2} \mathrm{O}\right)\right] \times 100$

where $\mathrm{CaO}^{*}$ is the amount of $\mathrm{CaO}$ incorporated in the silicate fraction of the rock. Correction for $\mathrm{CaO}$ from carbonate contribution was not done in this study due to the absence of $\mathrm{CO}_{2}$ value. Thus, to compute $\mathrm{CaO} *$ from the silicate fraction, the assumption proposed by Bock et al. (1998) was adopted. In this regard, $\mathrm{CaO}$ values were accepted only if $\mathrm{CaO}<\mathrm{Na}_{2} \mathrm{O}$; consequently, when $\mathrm{CaO}>\mathrm{Na}_{2} \mathrm{O}$, it was assumed that the concentration of $\mathrm{CaO}$ equals that of $\mathrm{Na}_{2} \mathrm{O}$. This procedure provides a measure the ratio of the secondary aluminous mineral to feldspar, and 
forms a basis for the measure of the intensity of weathering. Chemical Index of Weathering was calculated using the equation proposed by Harnois (1988).

$\mathrm{CIW}=\left[\mathrm{Al}_{2} \mathrm{O}_{3} /\left(\mathrm{Al}_{2} \mathrm{O}_{3}+\mathrm{CaO}+\mathrm{Na}_{2} \mathrm{O}\right)\right] \times 100$

In order to estimate the contribution of elements from other than natural sources, enrichment factors $(\mathrm{EF})$ with respect to the composition of Upper Crust (Wedephol 1995) were calculated.

$\mathrm{EF}=(X / \mathrm{Al})_{\text {sample }} /(X / \mathrm{Al})_{\text {Upper Crust }}$

where, $(X / \mathrm{Al})_{\text {sample }}$ represents the measured element/aluminum ratio of the sample and $(X / \mathrm{Al})$ Upper Crust represents the corresponding element/aluminum ratio in the Upper Crust. The Igeo values were calculated for the surface sediments of study area using the equation after (Muller 1979).

Igeo $=\log _{2}[\mathrm{Me}]_{\text {studied area }} / 1.5[\mathrm{Me}]_{\text {baseline value }}$

in which, $[\mathrm{Me}]$ baseline value represents the metal concentration in the average crust values taken from Wedepohl (1995) since the standard background values for Indian soils are not available and Indian geochemical soil base line map project has been just initiated under the Global Geochemical Baselines Program (Srinivasa Goud et al. 2010). The 1.5 factor is included because of possible variations in the background data due to lithogenic effects (Salomons and Forstner 1984).

\section{Present scenario of the Study Area}

Chennai is one of the main metropolitan cities in South India and the capital of Tamil Nadu State. Unlike other districts, Chennai City includes both urban and rural areas, and is treated as a separate district. It is one of the 29 districts in Tamil Nadu. Chennai has emerged as an important centre for economical, historical, and 
cultural and trade development in the state over the last few decades. The population density in the city was 24,682 per $\mathrm{km}^{2}$ in 2001 , which makes it one of the most densely populated cities in the world. Chennai experiences a tropical wet and dry climate. The average annual rainfall is $\sim 1,300 \mathrm{~mm}$. The city receives most of its seasonal rainfall from the north-east monsoon from mid-October to midDecember. The maximum temperature is around $38-42{ }^{\circ} \mathrm{C}$ (May - June) and the minimum is $\sim 18-20{ }^{\circ} \mathrm{C}$ (January). There are three important waterways that crisscross Chennai: The Cooum and the Adyar rivers and the Buckingham Canal. The Cooum River (or Koovam) meanders through the centre of the city, while the Adyar River flows through its southern part and both rivers are dreadfully polluted with sewage, effluent and garbage. The average discharge of the Adyar River is estimated as $114 \times 10^{6} \mathrm{~m}^{-3}$ (Ramesh et al. 2002). The sedimentation rate of Cooum and Adyar Rivers vary between 5.28 and $10.40 \mathrm{~mm} \mathrm{yr}^{-1}$ with an average of $7.85 \mathrm{~mm} \mathrm{yr}^{-1}$ (Ramesh et al. 2002). The Kortalaiyar River, flows through the northern fringes of the city before draining into the Bay of Bengal at Ennore.

The Buckingham Canal is a $420 \mathrm{~km}$-long fresh water navigation canal, running parallel to the east coast of South India from Marakkanam (Villupuram District) in Tamil Nadu to Peddaganjam near Vijayawada (Krishna District) in Andhra Pradesh. This Canal runs parallel to the shoreline, in a north-south direction, conveys industrial and domestic wastes to Pulicat Lake and eventually to the Bay of Bengal. It also connects most of the natural backwaters along the coast to the port of Chennai (Madras). During the British Period, ( 1600 to1947: British India) the canal provided drinking water and was also used for other commercial purposes such as navigations. The portion south of the Cooum River as South Buckingham Canal (SBC; Sample Numbers BC 01-12) and the portion north of the Cooum River is known as North Buckingham Canal (NBC: Sample 
Numbers BC 13-22) (Fig.1). About $257 \mathrm{~km}$ length of the canal passes through Andhra Pradesh State, and the rest of it in Tamil Nadu State. About $31 \mathrm{~km}$ of the canal runs within the Chennai city limit. The canal was formerly used to ferry goods up and down the coast to Chennai. It was damaged by the cyclones in1965/1966 and 1976, and no longer used or maintained. Within Chennai city, the canal is noticeably polluted from sewage and industrial effluents. It is also silting up, which causes stagnant water, an attractive habitat for malaria-bearing mosquitoes and other water borne diseases. The sedimentation rate of the Buckingham Canal was estimated as $14.3 \mathrm{~mm} \mathrm{yr}^{-1}$ by Purvaja and Ramesh (2000). In the present study, samples were collected from Sholinganallur in the south to Ennore in the north of Chennai (Fig. 1).

Two important solid waste landfills and Pallikkarani marsh land are located in the study area. The two designated landfills are Perungudi in SBC and Kodugaiyur in NBC. They are currently being used as open dumps for the disposal of Chennai's municipal solid waste. The average waste generation in Chennai was 4,800 tons per day but has increased to 6,000 tons per day (Vasanthi et al. 2008). The Perungudi solid waste landfill site is located $\sim 2-3 \mathrm{~km}$ west of the Buckingham Canal, close to the Pallikaranai Depression, which stretches $\sim 10 \mathrm{~km}$ north to south and $\sim 3 \mathrm{~km}$ west to east. This low lying area is connected to the sea through the Buckingham Canal and the Kovalam Estuary at the southern end of the depression. In NBC, a number of large industries are located in the Manali and Ennore industrial estates: North Chennai Thermal Power Station (NCTPS), Tamil Nadu Petro Products (TNPP) Ltd, Madras Fertilisers Limited (MFL) unit, Indian Oil Corporation (IOC), Chennai Petrochemicals Limited (CPCL), Southern Railway Carriage Works Division, a sewage treatment plant and Kodungaiyur landfill site. 


\section{Results and Discussion}

\subsection{Distribution of Elements}

The concentration of elements in the surface sediments of Buckingham Canal are shown in Table.1. The average concentrations of $\mathrm{Al}$ (overall avg. $\mathrm{n}=22 ; 53986 \mu \mathrm{g}$ $\left.\mathrm{g}^{-1}\right), \mathrm{Ca}\left(24531 \mu \mathrm{g} \mathrm{g}^{-1}\right), \operatorname{Mg}\left(5983 \mu \mathrm{g} \mathrm{g}^{-1}\right), \mathrm{Fe}\left(30997 \mu \mathrm{g} \mathrm{g}^{-1}\right), \quad \mathrm{Ti}\left(2583 \mu \mathrm{g} \mathrm{g}^{-1}\right), \mathrm{Mn}$ (342.25 $\left.\mu \mathrm{g} \mathrm{g}^{-1}\right), \mathrm{Cr}\left(396.95 \mu \mathrm{g} \mathrm{g}^{-1}\right), \mathrm{V}\left(70.91 \mu \mathrm{g} \mathrm{g}^{-1}\right)$, Mo $\left(40.17 \mu \mathrm{g} \mathrm{g}^{-1}\right)$, and As $\left(10.05 \mu \mathrm{g} \mathrm{g}^{-1}\right)$ are higher in the sediments from SBC (Sample Nos: BC 1-12) than NBC (Sample Nos: BC 13-22). Average concentrations of Si (overall avg. $\left.275436 \mu \mathrm{g} \mathrm{g}^{-1}\right), \mathrm{Na}\left(8016 \mu \mathrm{g} \mathrm{g}^{-1}\right), \mathrm{K}\left(13913 \mu \mathrm{g} \mathrm{g}^{-1}\right), \mathrm{P}\left(3565 \mu \mathrm{g} \mathrm{g}^{-1}\right), \operatorname{Sr}(241.31$ $\left.\mu \mathrm{g} \mathrm{g}^{-1}\right), \mathrm{Ba}\left(561.91 \mu \mathrm{g} \mathrm{g}^{-1}\right), \operatorname{Sn}\left(26.06 \mu \mathrm{g} \mathrm{g}^{-1}\right), \mathrm{Cu}\left(257.5 \mu \mathrm{g} \mathrm{g}^{-1}\right), \mathrm{Pb}\left(80.47 \mu \mathrm{g} \mathrm{g}^{-1}\right)$, $\mathrm{Zn}\left(422.11 \mu \mathrm{g} \mathrm{g}^{-1}\right), \mathrm{Ni}\left(36.76 \mu \mathrm{g} \mathrm{g}^{-1}\right)$ and $\mathrm{Hg}\left(1.64 \mu \mathrm{g} \mathrm{g}^{-1}\right)$ are higher in NBC than SBC sediments (Fig. 2). The major and trace metal concentration in these sediments decrease in the following order: $\mathrm{Si}>\mathrm{Al}>\mathrm{Fe}>\mathrm{Ca}>\mathrm{K}>\mathrm{Na}>\mathrm{Mg}>\mathrm{P}>\mathrm{Ti}$ and $\mathrm{Ba}>\mathrm{Zn}>\mathrm{Cr}>\mathrm{Mn}>\mathrm{Cu}>\mathrm{Sr}>\mathrm{Pb}>\mathrm{V}>\mathrm{Mo}>\mathrm{Ni}>\mathrm{Sn}>\mathrm{As}>\mathrm{Hg}$. The higher concentration of heavy metals as $\mathrm{Sn}\left(37.48 \pm 12.00 \mu \mathrm{g} \mathrm{g}^{-1}\right), \mathrm{Cu}\left(282.03 \pm 368.79 \mu \mathrm{g} \mathrm{g} \mathrm{g}^{-1}\right), \mathrm{Pb}$ $\left(83.67 \pm 57.74 \mu \mathrm{g} \mathrm{g}^{-1}\right), \mathrm{Zn}\left(455.58 \pm 373.91 \mu \mathrm{g} \mathrm{g}^{-1}\right), \mathrm{Ni}\left(46.00 \pm 55.78 \mu \mathrm{g} \mathrm{g}^{-1}\right)$, and $\mathrm{Hg}$ $\left(2.04 \pm 0.63 \mu \mathrm{g} \mathrm{g}^{-1}\right)$ in NBC sediments indicate the threats by industries located in the northern part of Buckingham Canal (Fig.3). Some of the heavy metals such as $\mathrm{Zn}, \mathrm{Pb}, \mathrm{Cu}$ and $\mathrm{Ni}$ are enriched at certain locations (BC 2-5, 10-11, 14, 18-20 and 22) that are related to the point sources (Fig. 3). The high concentrations of $\mathrm{Pb}, \mathrm{Cd}$ and $\mathrm{Zn}$ suggest that the sediments are contaminated by the industrial activities, atmospheric deposition of finer particles from fly ash dump area, and domestic effluent discharges. Cobalt, $\mathrm{Pb}, \mathrm{Sn}$, and $\mathrm{Zn}$ are known markers of paint industries 
(Lin et al. 2002), and are found to be enriched in the sediments of NBC (Fig. 3). This clearly indicates the influence of effluents from industrial area. Most of the heavy metals, particularly in SBC, are derived from leachates of Perungudi solid wastes, polluted Pallikkarani marsh land and the influence of Adyar River (eg. Achyuthan et al. 2002; Jayapraksh et al. 2010; and Vasanthi et al. 2008). According to Vasanthi et al. (2008) the presence of heavy metals like $\mathrm{Cd}, \mathrm{Cr}, \mathrm{Cu}$, $\mathrm{Zn}, \mathrm{Pb}$ and $\mathrm{Fe}$ in the leachate due to the effect of unsegregated solid waste containing steel scrap, lead batteries, tins, cans etc. affects the ground water through high total dissolved solids, EC, total hardness, chlorides, COD, nitrates and sulfates. The higher values of $\mathrm{Cr}, \mathrm{Co}, \mathrm{Zn}$ and $\mathrm{Sn}$ are attributed to the corrosion of steel and other alloys, (chrome plating and pigment production), which are generally used in many industries (electroplating industries, railway carriage works, trunk factories) located in the northern part of the study area (Achyuthan et al. 2002; Jonathan et al. 2004). The average Ni content, $28.82 \mu \mathrm{g} \mathrm{g}^{-}$ ${ }^{1}$ in SBC sediments is comparable with the previous study from Adyar Estuary (18 and $38 \mu \mathrm{g} \mathrm{g}^{-1}$ ) by Achyuthan et al. (2002). High Ni concentration is recorded in NBC 20 (168.9 $\mu \mathrm{g} \mathrm{g}^{-1}$; Fig.3), which clearly indicates the effects of effluents originating from Manali industrial estate. The overall enrichment of $\mathrm{Cu}, \mathrm{Zn}, \mathrm{Pb}$ and $\mathrm{Hg}$ in both NBC $\left(282 \mu \mathrm{g} \mathrm{g}^{-1}, 456 \mu \mathrm{g} \mathrm{g}^{-1}, 84 \mu \mathrm{g} \mathrm{g}^{-1}\right.$, and $\left.2 \mu \mathrm{g} \mathrm{g}^{-1}\right)$ and SBC sediments (233 $\mu \mathrm{g} \mathrm{g}^{-1}, 389 \mu \mathrm{g} \mathrm{g}^{-1}, 77 \mu \mathrm{g} \mathrm{g}^{-1}$, and $1 \mu \mathrm{g} \mathrm{g}^{-1}$ ) point to their anthropogenic origin, which is strongly supported by the enrichment of some heavy metals $(\mathrm{Cu}, \mathrm{Ni}, \mathrm{Mo}, \mathrm{Pb}, \mathrm{Zn}$ and $\mathrm{Co}$ ) in soils (Krishna and Govil 2008) of Manali industrial area (northern part of the study area). Arsenic concentrations are mostly $<2 \mu \mathrm{g} \mathrm{g}^{-1}$ except in two samples from SBC (12.0 and $8.1 \mu \mathrm{g} \mathrm{g}^{-1}$ in locations 2 and 10, respectively). Enrichment of As in these two locations may be due to coal combustion and metallurgical industries (Navas and Machin 2002). 
This study is the first to document the concentrations of elements such as Mo and Sn in the Buckingham Canal sediments. A significant difference is observed in the Mo and Sn concentrations between NBC and SBC. Mo $\left(59.74 \pm 10.79 \mu \mathrm{g} \mathrm{g}^{-1}\right)$, is enriched in SBC sediments and $\mathrm{Sn}\left(37.48 \pm 12.00 \mu \mathrm{g} \mathrm{g}^{-1}\right)$ is enriched in NBC sediments (Fig. 3). Molybdenum is present mainly in the form of molybdate $\left(\mathrm{MoO}_{4}{ }^{2-}\right.$; Broecker and Peng 1982). Generally, the major enrichment of Mo in sedimentary environments is associated with permanently anoxic basins (e.g. Cariaco basin: Piper and Dean 2002) while its concentration is significantly lower in the surface sediments under oxic condition (Sundby et al. 2004). It is adsorbed to Mn oxyhydroxides and is also removed to anoxic sediments at high dissolved sulfide levels, which are maintained in the surface sediment by anoxic bottom waters. Anoxic sediments may contain Mo as much as $130 \mu \mathrm{g} \mathrm{g}^{-1}$ (Adelson et al. 2001). This element can be also high in oxic sediments, $\left(\sim 60 \mu \mathrm{g} \mathrm{g}^{-1}\right)$ due to Mo adsorption onto Mn oxyhydroxides (Bertine and Turekian 1973), but under suboxic conditions, such oxides dissolve and the adsorbed Mo is released to the pore water. However, the high concentration Mo in NBC sediments could be related to fluctuations in redox conditions such as local suboxic to anoxic conditions that prevail due to lack of flow and stagnation of polluted water. Molybdenum also occurs in fossil fuels and is immobilized by combustion, which can lead to contamination of sediments by atmospheric deposition, resulting from melting and smelting, and oil refining operations (Krishna and Govil 2008). Lack of flow in the Buckingham Canal has become a typical problem in the last three decades and pollution in this canal is almost out of control due to lack of flushing and accumulation of sediments (Sridhar, 1982). The waterway is anoxic with high levels of ammonia, BOD and heavy metals such as $\mathrm{Zn}, \mathrm{Cu}, \mathrm{Cr}$ and $\mathrm{Pb}$ (Appasamy and Lundqvist 1993). 
Tin is mainly used in alloys, electrical/electronic applications as well as in glass-making. In stream sediment, $\mathrm{Sn}$ is mostly detrital in nature. Resistant oxide phases such as cassiterite release Sn very slowly during weathering. If there is no evidence for $\mathrm{Sn}$ mineralisation in the source area, $\mathrm{Sn}$ is the best indicator for contamination. Sediments contamination is often indicated by the high concentrations of other heavy metals such as $\mathrm{Pb}, \mathrm{Zn}$ and $\mathrm{As}$, which are not associated with $\mathrm{Sn}$ mineralisation. A relevant modern source of $\mathrm{Sn}$ in canal sediments may be the paint industries since organotin compounds are used as antifouling agents (e.g. Antizar-Ladislao 2008). In the study area, Sn mineralization is unknown and hence, the high concentrations of tin may be related to past contamination from mills and smelters treating ores imported from other areas.

\subsection{Paleoweathering}

The composition of clastic sediments is strongly influenced by a number of factors such as chemical weathering in the source region, sediment transport in fluvial systems and sediment recycling (Nesbitt et al. 1997). The weathering history of sediments may be evaluated by examining the relationship between alkali and alkaline earth elements (Nesbitt and Young 1982). In order to quantify the degree of weathering, CIA and CIW indexes were calculated using the molecular proportions proposed by Nesbitt and Young (1982) and Harnois (1988). Unweathered igneous rocks have CIA values close to 50, whereas intensely weathered residual rocks forming the minerals kaolinite and gibbsite have values around 100 (Nesbitt and Young 1982). The average shales show CIA values ranging from 70 to 75 whereas residual clay varies between 85 and 100 (Taylor and McLennan 1985). The mean value of CIA (74.33) for the sediments in the 
present study is similar to the PAAS (CIA: 75.30) but higher than NASC (65.91) and UCC (59.86). The mean value of CIW (79.9) in the present study is slightly higher than that of NASC (77.99), UCC (70.39) and lower than PAAS (88.32). The calculated CIA and CIW values in the sediments are higher than the NASC and UCC but similar to PAAS, suggesting a source area of moderate weathering.

\subsection{Statistical analysis}

The primary trace elements influenced by $\mathrm{Mn}-\mathrm{Fe}$ cycling are $\mathrm{Ni}, \mathrm{Cu}, \mathrm{Zn}, \mathrm{Co}, \mathrm{Pb}$ (as "2+cations”), as well as $\mathrm{Mo}, \mathrm{V}$ and $\mathrm{Cr}$ (as ionic species such as $\mathrm{MoO}_{4}{ }^{2-}, \mathrm{VO}^{2+}$ and $\mathrm{Cr}(\mathrm{OH})^{2+}$, respectively). The trace metals transported from human activities are often associated with organic matter, absorbed on Fe-Mn hydrous oxides, and/or precipitated as hydroxides, sulfides and carbonates (Forstner 1983). Aluminum is well correlated with $\mathrm{Fe}, \mathrm{Ti}, \mathrm{Mg},(\mathrm{r}=>0.6)$ (Table 3), which indicates that these elements are likely to be associated with clay minerals. Aluminum, $\mathrm{K}$, and $\mathrm{Ti}$ are well correlated amongst them, indicating an unpolluted geogenic source. Iron has very strong correlation with other oxides, which have a higher affinity with most elements, particularly for trace elements (Stumm and Morgan, 1996). Iron shows a strong relationship with $\mathrm{Al}(\mathrm{r}=0.82)$ and $\mathrm{Mg}(\mathrm{r}=$ 0.75) and moderate correlation with the $\mathrm{P}, \mathrm{Ti}, \mathrm{Mn}, \mathrm{V}, \mathrm{Mo}, \mathrm{Pb}$ and $\mathrm{Hg}(\mathrm{r}=0.58$; $0.62 ; 0.62 ; 0.63 ; 0.63$ and 0.54 respectively) (Table 3 ). This suggests that they are closely associated with $\mathrm{Fe}$ and $\mathrm{Mn}$ oxides and that $\mathrm{Fe}$ is available in the form of oxide coating on sediment particles (Subramanian and Mohanachandran 1990). Zinc is not correlated with $\mathrm{Al}, \mathrm{Ti}$ and $\mathrm{Fe}(\mathrm{r}=0.08$; -0.36 ; and 0.09$)$ indicating that it was not associated with the Fe oxyhydroxide phase. Instead, it should be considered to be anthropogenic and this is confirmed by a significant correlation 
of $\mathrm{Zn}$ with $\mathrm{Pb}$, Sn and $\mathrm{P}$. Lead did not correlate either with $\mathrm{Al}(\mathrm{r}=0.39)$ or $\mathrm{K}(\mathrm{r}=-$ 0.27), which confirms that $\mathrm{Pb}$ is present in the sediments as $\mathrm{Pb}\left(\mathrm{CO}_{3}\right)_{2}$, as shown by its strong correlation with $\mathrm{Ca}(\mathrm{r}=0.72)$. Calcium shows a strong to moderate negative relationship with $\mathrm{Si}(\mathrm{r}=-0.83)$ and $\mathrm{Na}(\mathrm{r}=-0.59)$, but shows a significantly positive relationship with $\mathrm{P}, \mathrm{Hg}, \mathrm{Pb}, \mathrm{Mg}$ and $\mathrm{Zn}$, indicating that variable amounts of shell/skeletal fragments act as scavengers for trace metals like $\mathrm{Cd}, \mathrm{Co}, \mathrm{Cr}, \mathrm{Ni}, \mathrm{Zn}$ and $\mathrm{Pb}$. Vanadium normally substitutes for $\mathrm{Fe}$ in ferromagnesian minerals and in Buckingham Canal sediments, positive correlations between $\mathrm{V}$ and $\mathrm{Fe}, \mathrm{Ti}, \mathrm{Al}$ and $\mathrm{Mg}$ respectively $(\mathrm{r}=0.63 ; 0.71 ; 0.59$; 0.54) were noted, indicating that the distribution of $\mathrm{V}$ is controlled by ironbearing detrital minerals and not due to pollution.

Varimax rotation (Gotelli and Ellison 2004) was used to maximize the sum of the variance of factor coefficients. As shown in Figure 4, factor 1 accounted for $31.10 \%$ of the total variance and is characterised by high positive loadings of $\mathrm{Ca}$, $\mathrm{Mg}, \mathrm{P}, \mathrm{Pb}, \mathrm{Zn}, \mathrm{Ni}, \mathrm{Hg}$ and high negative loadings of $\mathrm{Si}$ and $\mathrm{Na}$. Lead and $\mathrm{Zn}$ have strong association with $\mathrm{Ca}$, indicating incorporation of these metals in the carbonate debris present in the sediments. Factor 2 accounted for $17.4 \%$ of the total variance and is characterised by high positive loadings of $\mathrm{Al}, \mathrm{Fe}, \mathrm{Ti}, \mathrm{Mn}$, and V (Fig. 4). It is well established that iron and manganese oxides are excellent scavengers for trace metals (Stumm and Morgan 1996). Aluminum, Fe, Ti are associated with Fe-Mn, indicates that Fe-Mn oxyhydroxides play a major role in the uptake of the metals in the sediments (Jayaprakash et al. 2008). Also, Al is well correlated with $\mathrm{Fe}, \mathrm{Ti}, \mathrm{Mg},(\mathrm{r}=>0.6)$ and moderately correlated with $\mathrm{V}(\mathrm{r}=$ 0.59), thereby indicating that these elements are related to a natural geogenic source. Factor 3 explained $16.51 \%$ of the total variance and is supported by high 
positive loadings of $\mathrm{Ba}$ and $\mathrm{Sn}$, and a strong negative loading of Mo (Fig. 4). Tin is an excellent indicator of contamination and shows good correlation with $\mathrm{Pb}, \mathrm{Zn}$ and $\mathrm{As}$, also indicating that $\mathrm{Sn}$ is derived from anthropogenic sources since $\mathrm{Pb}, \mathrm{Zn}$ and As are not associated with Sn mineralisation. The important anthropogenic sources of tin are coal and wood combustion, waste incineration and sewage sludge (Reimann and de Caritat 1998), alloys such as use of solder ( $\mathrm{Sn}-\mathrm{Pb}$ ), use of agricultural pesticides and wood treatment with preservatives in which organo-Sn compounds have been used. These processes are common in and around the study area, and are the expected source for anthropogenic $\mathrm{Sn}$ in these sediments. Enrichment of Mo in SBC and its negative loading in this factor indicates that Mo is mostly related to sub-oxic to anoxic depositional conditions in the canal, which leading to enrichment of $\mathrm{Mo}$ in these sediments. Chromium, $\mathrm{Cu}, \mathrm{Pb}$, and $\mathrm{Ni}$ are positively loaded in factor 4 that accounts for $14.49 \%$ of the total variance (Fig. 4). The $\mathrm{Cr}$ and $\mathrm{Cu}$ contents in the sediments indicate the influence of industrial and domestic waste, iron and steel industries and sewage. The Ni content in sediments may be due to petroleum-related industrial activity (Vazquez and Sharma 2004) and a number of oil refineries are located in northern part of the study area. Also, $\mathrm{Cr}, \mathrm{Cu}, \mathrm{Pb}$, and $\mathrm{Ni}$ are well correlated among themselves, clearly supporting the hypothesis of an anthropogenic origin. Factor 5 accounts for $8.96 \%$ of the total variance and is positively loaded by $\mathrm{K}, \mathrm{Sr}$ and $\mathrm{Al}$ (Fig. 4). Potassium will be associated with clay minerals, illite in particular, rather than in the calcite lattice (Neal 2002). Potassium and Al are associated with clay minerals and Sr has a close relationship with these two metals indicating that these three metals derive from a natural geogenic source rather than an anthropogenic one. 
Cluster analysis was also performed on all the parameters in the canal sediments. The results are illustrated in a dendrogram (Fig.5). Two major clusters are observed. Cluster 1 consists of two sub-clusters: $\mathrm{Hg}$, As, Ni, Sn, Ba and $\mathrm{Mn}$ in sub-cluster 1; and $\mathrm{Zn}, \mathrm{Pb}, \mathrm{Cu}, \mathrm{Ni}, \mathrm{Cr}, \mathrm{P}, \mathrm{Mg}$ and $\mathrm{Ca}$ in sub-cluster 2. Cluster 2 also consists of two sub-clusters as geogenic elements ( $\mathrm{Al}, \mathrm{Si}, \mathrm{Ti}, \mathrm{Na}, \mathrm{K})$ and redox sensitive elements $(\mathrm{Fe}, \mathrm{Mo}$, and $\mathrm{V}) . \mathrm{Hg}, \mathrm{As}, \mathrm{Ni}$, As and $\mathrm{Ba}$ shows different linkage among them, indicating the diversity of possible anthropogenic sources such as industrial effluents, domestic effluents, and leachates from landfill sites. Alkaline earth metals such as $\mathrm{Sr}$ and $\mathrm{Ba}$ are known to be relatively mobile in natural oxic and aqueous environments; $\mathrm{Sr}$ is not associated with $\mathrm{Ca}$. Tin shows good correlation with $\mathrm{Ba}(\mathrm{r}=0.85)$, and the sub-cluster formed by these two metals, is associated with $\mathrm{Mn}$ rather than $\mathrm{Fe}$. Zinc, $\mathrm{Pb}, \mathrm{Cu}, \mathrm{Ni}$ and $\mathrm{Cr}$ show moderate correlation among themselves, indicate that these metals are derived from domestic and industrial effluents. Also, these elements are associated with $\mathrm{Ca}$, indicating that shell/skeletal fragments act as scavengers for the trace metals (Co, $\mathrm{Cr}, \mathrm{Ni}, \mathrm{Zn}$ and $\mathrm{Pb}$ ). This is further supported by $\mathrm{Pb}$ and $\mathrm{Zn}$ and their significant correlation with $\mathrm{Ca}$. Molybdenum and $\mathrm{V}$ are grouped in cluster 3, mostly associated with the depositional condition in the canal. Vanadium may be bound to $\mathrm{OM}$ by the incorporation of $\mathrm{V}^{4+}$ into porphyrins, and is generally found in sediments deposited in reducing environments. It is less available under oxic conditions but gets enriched during redox conditions and behaves similarly to Mo. Vanadium accumulates from seawater under both suboxic and anoxic conditions, whereas Mo accumulates predominantly under the more reducing anoxic conditions. Vanadium shows strong relationship with Mo $(\mathrm{r}=0.76)$, confirming an origin similar to that of Mo. This indicates that these elements are associated 
with local anoxic conditions in the canal and these elements are also associated with Fe.

\subsection{Enrichment Factor}

Enrichment of trace elements can be evaluated by geochemical normalization of metal concentrations with a conservative element like Al, since this element is a proxy for the clay mineral concentration (Kersten and Smedes 2002). This method has been widely used to assess the enrichment or depletion specific elements in riverine, estuarine and coastal environments (eg. Muthuraj and Jayaprakash 2008; Selvaraj et al. 2004; Zhang and Liu 2002). In general, the degree of enrichment or depletion of a trace element in a sample is evaluated relative to its concentration in a reference that is commonly the average crustal rocks or average shale (Taylor and McLennan 1985; Wedepohl 1995).

Distribution of EF (Enrichment Factor) for the trace elements is shown in Figure 6 . The EF values $<2$ can be considered as natural origin and values $>2$ is suggestive of anthropogenic sources (Grousset et al. 1995). In general, EF $<10.0$ is not considered as important since such small enrichments may arise from differences in the composition of local soil material and reference soil used in EF calculations (Pekay 2006). The calculated average EF values for the surface sediments of Buckingham Canal can be shown as

$$
\begin{aligned}
& \mathrm{Mo}>\mathrm{Hg}>\mathrm{Cu}>\mathrm{Cr}>\mathrm{Zn}>\mathrm{Sn}>\mathrm{P}>\mathrm{As}>\mathrm{Pb}>\mathrm{V}>\mathrm{Ni}>\mathrm{Ba}>\mathrm{Mn}[\mathrm{SBC}] \\
& \mathrm{Hg}>\mathrm{Sn}>\mathrm{Cu}>\mathrm{Zn}>\mathrm{Cr}>\mathrm{Mo}>\mathrm{P}>\mathrm{Pb}>\mathrm{Ni}>\mathrm{Ba}>\mathrm{V}>\mathrm{Mn}>\mathrm{As}[\mathrm{NBC}]
\end{aligned}
$$

The variation in EF values between SBC and NBC is shown in Figure 6. Overall, the average enrichment factors of Fe $(1.30 \pm 0.47), \mathrm{Mn}(0.63 \pm 0.22), \mathrm{Sr}$ (1.13 \pm 0.29$), \mathrm{Ba}(1.28 \pm 0.67)$, and $\mathrm{V}(1.89 \pm 1.07)$ are found to be $<2$ in the 
sediments suggesting that these metals can be considered to be from a natural crustal source. In contrast, the average enrichment factor of $\mathrm{P}(7.51 \pm 4.68), \mathrm{Cr}$ (16.16 \pm 11.8$), \quad \mathrm{Sn} \quad(16.24 \pm 10.4), \quad \mathrm{Cu} \quad(20.55 \pm 13.8), \quad \mathrm{Pb} \quad(6.67 \pm 4.25), \quad \mathrm{Zn}$ (11.32 \pm 8.39$)$, Ni (2.73 \pm 3.43$)$, As $(6.47 \pm 2.29)$ and $\mathrm{Hg}(46.26 \pm 21.7)$ are found to be $>2$, suggesting contamination of these metals in the Buckingham Canal sediments. Though the EF for As is high $(\mathrm{EF}>2)$, it is not shown at all the sampling stations. Some authors have suggested that the EF close to unity points to crustal origin, whereas EF values $>10$ are considered to be indicative of noncrustal origin (e.g. Pekay 2006; Selvaraj et al. 2004). If we consider, EF > 10 in the present study, $\mathrm{Cr}, \mathrm{Sn}, \mathrm{Cu}, \mathrm{Zn}, \mathrm{Mo}$ and $\mathrm{Hg}$ are enriched in these sediments, which are mainly derived from domestic sewage and industrial activities. The enrichment is seen at certain locations, related to local point sources. Unplanned industrialization and indiscriminate disposal of untreated effluents into the adjoining rivers in Chennai City has probably resulted in anomalous distribution of certain elements, such as $\mathrm{Mn}, \mathrm{Zn}, \mathrm{Cu}, \mathrm{Cr}, \mathrm{Ni}$ (Ramesh et al. 2002).

The current trace metal concentrations were compared with those of the adjacent areas (rivers, lakes, sea) and other similar type of studies. $\mathrm{Zn}, \mathrm{Pb}, \mathrm{Cu}, \mathrm{Cr}$ and $\mathrm{Hg}$ concentrations are increased two-to eight-times higher than the source region and the adjacent parts of the study area (Table 2). Iron, $\mathrm{Cr}$, and $\mathrm{V}$ concentrations are more or less similar to the concentrations recorded in Pallikaranai marsh sediments (Jayaprakash et al. 2010).

\subsection{Geoaccumulation index $\left(I_{\text {geo }}\right)$}

The geoaccumulation index ( $\left.\mathrm{I}_{\text {geo }}\right)$, introduced by Muller (1981), has been used to quantitatively measure metal pollution in aquatic sediments (e.g. Muthuraj and 
Jayaprakash 2008) based on a pollution intensity classification ( $\mathrm{I}_{\text {geo }}$ Class). This classification consists of seven classes (0-6; Table 4), the highest class reflects 100-fold enrichment over the baseline values. As shown in Table 4, the results of the calculated $I_{\text {geo }}$ values from this study are -2.21 to 0.10 for $\mathrm{Fe},-1.58$ to 2.88 for $\mathrm{P},-2.99$ to -0.87 for $\mathrm{Mn}, 0.09$ to 4.27 for $\mathrm{Cr},-1.87$ to -0.42 for $\mathrm{Sr},-4.04$ to 0.07 for $\mathrm{Ba},-3.73$ to 1.04 for $\mathrm{V}, 0.98$ to 3.93 for $\mathrm{Sn}, 1.78$ to 5.34 for Mo, 0.60 to 5.93 for $\mathrm{Cu},-0.78$ to 2.76 for $\mathrm{Pb},-0.44$ to 4.02 for $\mathrm{Zn}, 1.43$ to $2.00(\mathrm{n}=2)$ for As and 2.84 to 5.46 for $\mathrm{Hg}$.

The average geoaccumulation indexes are less than zero for most of the elements suggesting that the sediments have not been polluted overall by these metals. Results from this exercise indicate that $40.41 \%$ of the elements belong to Igeo class 0 and $10.51 \%$ of the elements belong to $\mathrm{I}_{\text {geo }}$ class 1 (unpolluted to moderately polluted). The remaining $48.83 \%$ of the elements ( $\mathrm{P}, \mathrm{Sn}, \mathrm{Mo}, \mathrm{Pb}, \mathrm{Cu}, \mathrm{Zn}$ and $\mathrm{Hg}$ ) belong to Igeo $_{\text {ge }}$ class 2-6 (Moderate - extremely polluted). Overall, sediments collected from SBC are highly enriched in $\mathrm{Mo}, \mathrm{Zn}, \mathrm{Cu}$, and $\mathrm{Hg}$, which belong to Igeo class 4-6, whereas sediments collected from $\mathrm{NBC}$ are enriched in $\mathrm{Sn}, \mathrm{Cu}, \mathrm{Zn}$ and $\mathrm{Hg}$ ( $\mathrm{I}_{\mathrm{geo}}$ class 4-6).

\subsection{Contamination factor}

The level of contamination of metals in sediments is expressed by the contamination factor (CF), suggested by Pekay et al. (2004) which is the ratio between the sediment metal content at a given station and normal concentration levels (NCLs). Contamination factors $>1$ indicate contamination by the element while $\mathrm{CF}<1$ indicates no contamination. We have used average upper crust values reported by Wedephol (1995). The CF was classified into four groups as 
$\mathrm{CF}<1$ (low), $1 \leq \mathrm{CF}<3$ (moderate), $3 \leq \mathrm{CF}<6$ (considerable) and $\mathrm{CF} \geq 6$ (very high) (Pekay et al. 2004). The average values of CF for the surface samples of Buckingham Canal are shown in Figure 7. The average level of metals can be shown as $\mathrm{Mo}>\mathrm{Hg}>\mathrm{Cu}>\mathrm{Cr}>\mathrm{Zn}>\mathrm{Sn}>\mathrm{P}>\mathrm{Pb}>\mathrm{V}>\mathrm{Ni}>\mathrm{As}[\mathrm{SBC}]$ $\mathrm{Hg}>\mathrm{Cu}>\mathrm{Sn}>\mathrm{Zn}>\mathrm{Cr}>\mathrm{Mo}>\mathrm{P}>\mathrm{Pb}>\mathrm{Ni}>\mathrm{V}>\mathrm{As}[\mathrm{NBC}]$

Sediments of SBC are highly contaminated by $\mathrm{Mo}, \mathrm{Hg}$ and $\mathrm{Cu}$, whereas sediments of NBC are highly contaminated by $\mathrm{Hg}, \mathrm{Cu}$ and $\mathrm{Sn}$. This clearly shows that SBC is contaminated by the leachates of Perungudi landfill and Adyar River while NBC is contaminated by Cooum River and the industries located near the NBC. This observation is fully supported by the $I_{\text {geo }}$ Indices of these sediments.

\subsection{Biological effects of TTMs}

At elevated concentrations, many heavy metals become highly toxic and have chronic effects to living organisms. In the present study, various heavy metals in the Buckingham Canal sediments have been computed to Effects-Range Low (ERL) and Effects-Range Median (ERM) guidelines derived from Long et al. (1995) to evaluate the degree of contamination connected with biological effects. Sediment chemical concentrations below ERL are interpreted as having rarely associated with adverse effect; exceedance of ERM values and maximum baseline values were used to identify metals of ecological concern. The adverse effects of heavy metals in the sediments of Buckingham Canal are presented in Table 5. In SBC, the average concentration of $\mathrm{Cr}$ is greater than ERM and the adverse effect at most of the stations during the sampling period was given as $66.67 \%$, indicating possible detrimental effects to benthic organisms. In the case of $\mathrm{Cu}$, some stations 
show values higher than ERM and the biological effect of $\mathrm{Cu}$ is $33.33 \%$. Lead concentration in the sediment for SBC is between ERL and ERM with an effect of 66.67\%. In the case of $\mathrm{NBC}, \mathrm{Pb}$ content in the sediments is also found to be ERL ERM with an adverse effect of $0 \%$ for all stations. $\mathrm{Cu}, \mathrm{Ni}$ and $\mathrm{Cr}$ values are $>$ ERM and hence the biological adverse effect of these metals are $20 \%$; $\mathrm{Zn}$, which accounts $50 \%$ in NBC sediments, has more biological adverse effect than other metals in these sediments (Fig. 8).

\section{Conclusions}

A baseline data for the total trace metals in Buckingham Canal sediments has been generated and their concentrations clearly indicate that the trace metals are well persistent in the shallow environment. Chemical index of alteration and chemical index of weathering values are higher than the North American shale composite and upper continental crust and similar to post Archaean average shale, indicating a moderate source area weathering. The spatial distribution of total trace metals is also controlled by other factors like geochemical processes, precipitation and flocculation of particulate substances in the canal. Rapid urbanisation and industrialization in Chennai City, especially on the northern part, yields uncontrolled input of sewage, garbage and industrial effluents into the Buckingham Canal and the elevated concentration of trace metals is not unexpected in view of this situation. The level of enrichment of trace metals has also increased by 30 to $70 \%$ for most of the elements when compared with all other ecosystems in the world as well as nearby locations in the study area. The results also indicate that the sediments of south Buckingham Canal are contaminated with $\mathrm{Mo}, \mathrm{Hg}$ and $\mathrm{Cu}$ metals, whereas sediments of north 
Buckingham Canal are highly contaminated with $\mathrm{Hg}, \mathrm{Cu}$ and $\mathrm{Sn}$. This clearly shows that south Buckingham Canal is contaminated by leachates of landfill and the Adyar River. North Buckingham Canal is contaminated by Cooum River and industrial effluents from the industries located near the canal. The geoaccumulation index, enrichment factor and contamination factor values also support this observation. Hence, the present levels of trace metals should be taken into account and monitored frequently to categorize whether the level of trace metals is stable, increasing or decreasing, and if pollution control measures are needed in the aquatic regions of Chennai City limits.

\section{Acknowledgements}

The Author (M.Jayaprakash) is grateful to the Department of Science and Technology, Government of India, New Delhi, for the award of advanced research fellowship under the Better Opportunities for Young Scientist to Conduct Advance areas of Science and Technology (BOYSCAST'2009) programme. RN wishes to express his gratefulness to the Curtin Sarawak Research Institute Academic Grant (CSRI2011/Grants/01) for financial assistance. We are very grateful to anonymous reviewers for their valuable and constructive comments. My colleague, Dr. Dominique Dodge-Wan is also thanked for comments, suggestions and linguistic corrections. This article is the $61^{\text {st }}$ contribution from Earth System Science Group (ESSG), Chennai, India.

\section{References}

Achyuthan, H., Richardmohan, D., Srinivasaslu, S., \& Selvaraj, K. (2002). Trace metals concentrations in the sediment cores of estuary and tidal zones between Chennai and Pondicherry along the east coast of India. Indian Journal of Marine Sciences, 31, 141-149. 
Adelson, J. M., Helz, G. R., \& Millermm C. V. (2001). Reconstructing the rise of recent coastal anoxia; molybdenum in Chesapeake Bay sediments. Geochimica et Cosmochimica Acta, $65,237-252$.

Antizar-Ladislao, B. (2008). Environmental levels, toxicity and human exposure to tributyltin (TBT)-contaminated marine environment: A review. Environment International, 34, 292 308 .

Appasamy, P., \& Lundqvist, J. (1993). Water supply and waste disposal strategies for Madras. Ambio 22, 442-2448.

Beiras, R., Bellas, J., Fernandez, Z., Lorenzo, J. I., \& Cobelo-Garcia, A. (2003). Assessment of coastal marine pollution in Galicia (NW Iberian Peninsula); metal concentrations in seawater, sediments and mussels (Mytilus galloprovincialis) versus embryo-larval bioassays using Paracentrotus lividus and Ciana intestinalis. Marine Environmental Research, 56, 531-553.

Bertine, K. K., \& Turekian, K. K. (1973). Molybdenum in marine sediments. Geochimica et Cosmochimica Acta, 37, 1415-1434.

Bock, B., McLennan, S. M., \& Hanson, G. N. (1998). Geochemistry and provenance of the Middle Ordovician Austin Glen Member (Normanskill Formation) and the Taconian Orogeny in New England. Sedimentology, 45, 635-655.

Broecker, W. S., \& Peng, T. H. (1982). Tracers in the Sea. Eldigo press, Columbia University, Palisades, NY. 689p.

Chen, C. T. A., Wann, J. K., \& Lou, J. Y. (2001). Aeolian flux of metals in Taiwan in the past 2600 years. Chemosphere, 43, 287-294. 
El-Nemr, A., Khaled, A., \& El-Sikaily, A. (2006). Distribution and statistical analysis of leachable and total heavy metals in the sediments of the Suez Gulf. Environmental Monitoring and Assessment, 118, 89-112.

Forstner, F. (1983). Assessment of metal pollution in rivers and estuaries. In: I. Thornton (Ed.), Applied environmental geochemistry, London: Academic Press.

Gotelli, N. J., \& Ellison, A. M. (2004). A Primer of Ecological Statistics. I (Ed), Sunderland, MA, USA: Sinauer Associates, 492p.

Grousset, F. E., Quetel, C. R., Thomas, B., Donard, O. F. X., Lambert, C. E., Quillard, F., \& Monaco, A. (1995). Anthropogenic vs. lithogenic origins of trace elements (As, Cd, Pb, Rb, $\mathrm{Sb}, \mathrm{Sc}, \mathrm{Sn}, \mathrm{Zn})$ in water column particles: northwestern Mediterranean Sea. Marine Chemistry, 48, 291-310.

Harnois, L. (1988). The CIW index: a new chemical index of weathering. Sedimentary Geology, $55,319-322$.

Jayaprakash, M., Jonathan, M. P., Srinivasalu, S., Muthuraj, S., Ram-Mohan, V., \& RajeshwaraRao, N. (2008). Acid-leachable trace metals in sediments from an industrialized region (Ennore Creek) of Chennai city, SE coast of India: An approach towards regular monitoring. Estuarine, Coastal and Shelf Science, 76, 692-703.

Jayaprakash, M., Urban, B., Velmurugan, P. M., \& Srinivasalu, S. (2010). Accumulation of total trace metals due to rapid urbanization in microtidal zone of Pallikaranai marsh, South of Chennai, India. Environmental Monitoring and Assessment, 170, 609-629.

Jonathan, M.P., Ram Mohan, V., \& Srinivasulu, S. (2004). Geochemical variation of major and trace elements in recent sediments of the Gulf of Mannar the southeast coast of India. Environmental Geology, 45(4), 466-480 
Kamala Kannan, S., Mahadevan, S., \& Krishnamoorthy, R. (2006). Characterization of a mercuryreducing Bacillus cereusstrain isolated from the Pulicat Lake sediments, south east coast of India. Archives of Microbiology, 185, 202-211.

Kaushik, A., Kansal, A., Santosh, Meena, Shiv Kumari, C. P., \& Kaushik. (2009). Heavy metal contamination of river Yamuna, Haryana, India: Assessment by Metal Enrichment Factor of the Sediments. Journal of Hazardous Materials, 164, 265-270.

Kersten, M., \& Smedes, F. (2002). Normalization procedures for sediments contaminants in spatial and temporal trend monitoring. Journal of Environmental Monitoring, 4, 109-115.

Klavins, M., Briede, A., Rodinov, V., Kokorite, I., Parele, E., \& Klavina, I. (2000). Heavy metals in river of Lativa. The Science of the Total Environment, 262, 175-183.

Krishna, A. K., \& Govil, P. K. (2008). Assessment of heavy metal contamination in soils around Manali industrial area, Chennai, Southern India. Environmental Geology, 54, 1465-1472.

Lin, S., Hsieh, I. J., Huang, K. M., \& Wang, C. H. (2002). Influence of the Yangtze River and grain size on the spatial variations of heavy metals and organic carbon in the East China Sea continental shelf sediments. Chemical Geology, 182, 377-394

Long, E., MacDonald, D., Smith, S., \& Calder, F. (1995). Incidence of adverse biological effects within ranges of chemical concentrations in marine and estuarine sediments. Environmental Management, 19, 81-97.

Martin, J. M., \& Whitfield, M. (1983). The significance of the river input of chemical elements to the ocean. In: I.C.S. Wong, E. Boyle, K.W. Bruland, J.D. Burton, \& E.D. Goldberg [Eds.], Trace metals in sea water. (pp. 265-296). Plenum.

Muller, G. (1979). Schwermetalle in den sediments des Rheins- Veranderungen Seitt. Umschan, 79, 778-783. 
Muller, G. (1981). Die Schwermetall belastung der sedimenten des Neckars und Seiner Nebenflusse. Chemiker-Zeitung 6, 157-164

Muthu Raj, S., \& Jayaprakash, M. (2008). Distribution and enrichment of trace metals in marine sediments of Bay of Bengal, off Ennore, south-east coast of India. Environmental Geology, $56,207-217$.

Nabi Bidhendi, G. R., Karbassi, A. R., Nasrabadi, T., \& Hoveidi, H. (2007). Influence of copper mine on surface water quality. International Journal of Environmental Science and Technology, 4, 85-91.

Navas, A., \& Machin, J. (2002). Spatial distribution of heavy metals and arsenic in soil of Aragon (northeast Spain), Controlling factors and environmental implications. Applied Geochemistry, 17, 961-973.

Neal, C. (2002). The mineralogy and chemistry of fine-grained sediments, Morphou Bay, Cyprus. Hydrology and Earth System Science, 6, 819-831.

Nesbitt, H. W., \& Young, G. M. (1982). Early Proterozoic climates and platemotions inferred from major element chemistry of lutites. Nature, 299, 715-717

Nesbitt, H. W., Fedo, C. M., \& Young, G. M. (1997). Quartz and feldspar stability, steady and non-steady-state weathering, and petro-genesis of siliciclastic sands and muds. Journal of Geology 105, 173-191.

Pastorinho, R. M., Telfer, T. C., \& Soares, A. M. V. M. (2010) Heavy metals in urban channel sediments of Aveiro City, Portugal. In: Hamamura, N., Suzuki, S, Mendo, S., Barroso, C. M., Iwata, H., \& Tanabe, S (Eds.), Interdisciplinary studies on environmental chemistrybiological Responses to Contaminants. pp.197-204. 
Pekay, H. (2006). Heavy metal pollution assessment in sediments of the Izmit Bay, Turkey. Environmental Monitoring and Assessment, 123, 219-231.

Pekay, H., Karakas, D., Ayberk, S., Tolun, L., \& Bakoglu, M. (2004). Ecological risk assessment using trace elements from surface sediments of Izmit Bay (Northeastern Marmara Sea) Turkey. Marine Pollution Bulletin, 48, 946-953.

Piper, D. Z., \& Dean, W. E. (2002). Trace element deposition in the Cariaco Basin, Venezuela Shelf, under sulfate-reducing conditions - A history of the local hydrography and global climate, $20 \mathrm{ka}$ to the present. US Geological Survey Professional Paper, 1670, 41p.

Purvaja, R., \& Ramesh, R. (2000). Human impacts on methane emission from mangrove systems in India. Regional Environmental Change, 1(2), 86-97.

Ramesh, R., Purvaja, R., Ramesh, S., \& James, R. A. (2002). Historical Pollution Trends in Coastal Environments of India. Environmental Monitoring and Assessment, 79, 151-176.

Ravichandran, S. (1987). Water quality studies on Buckingham Canal (Madras, India) - A discriminant analysis. Hydrobiologia, 154, 121-126.

Reimann, C., \& De Caritat, P. (1998). Chemical elements in the environment: fact sheets for the geochemist and environmental scientist. Heidelberg: Springer, p398.

Sajwan, K. S., Kumar, K. S., Paramasivam, S., Compton, S. S., \& Richardson, J. P. (2008). Elemental Status in Sediment and American Oyster Collected from Savannah Marsh/Estuarine Ecosystem: A Preliminary Assessment. Archives of Environmental Contamination and Toxicology, 54, 245-258.

Salomons, W., Forstner, U. (1984). Metals in hydrocycle. (pp. 63-98). Berlin, Springer. 
Selvaraj, K., Ram-Mohan, V., \& Szefer, P. (2004). Evaluation of metal contamination in coastal sediments of the Bay of Bengal, India: geochemical and statistical approaches. Marine Pollution Bulletin, 49, 174-185.

Seshan, B. R. R., Natesan, U., \& Deepthi, K. (2010). Geochemical and statistical approach for evaluation of heavy metal pollution in core sediments in southeast coast of India. International Journal of Environmental Science and Technology, 7 (2), 291-306

Shanthi, V., \& Gajendran, N. (2009). The impact of water pollution on the socio-economic status of the stakeholders of Ennore Creek, Bay of Bengal (India): Part I. Indian Journal of Science and Technology, 2(3), 66-79.

Sridhar, M. K. C. (1982). A Field Study of Estuarine Pollution in Madras, India. Marine Pollution Bulletin, 13, 7, pp. 233-236.

Srinivasa Gowd, S., Ramakrishna Reddy, M., \& Govil, P. K. (2010). Assessment of heavy metal contamination in soils at Jajmau (Kanpur) and Unnao industrial areas of the Ganga Plain, Uttar Pradesh, India. Journal of Hazardous Materials, 174, 113-121.

Stumm, W., \& Morgan, J. J. (1996). Aquatic chemistry: Chemical equilibria and rates in natural waters ( $3^{\text {rd }}$ ed.), New York: Wiley.

Subramanian, V., \& Mohanachandran, G. (1990). Heavy metals distribution and enrichment in the sediments of southern east coast of India. Marine Pollution Bulletin, 21, 324-330.

Sundby, B., Martinez, P., \& Gobeil, C. (2004). Comparative geochemistry of cadmium, rhenium, uranium and molybdenum in continental margin sediments. Geochimica et Cosmochimica Acta, 68, 2485-2493.

Taylor, S. R., \& McLennan, S. M. (1985). The Continental Crust: Its Composition and Evolution. London: Blackwell Scientific Publications. 312p. 
Vasanthi, P., Kaliappan, S., \& Srinivasaraghavan, R. (2008). Impact of poor solid waste management on ground water. Environmental Monitoring and Assessment, 143, 227-238.

Vazquez, F. G., \& Sharma, V. K. (2004). Major and trace elements in sediments of the Campeche Sound, southeast Gulf of Mexico. Marine Pollution Bulletin, 48, 87-90.

Wedepohl, K. H. (1995). The composition of the continental crust. Geochimica et Cosmochimica Acta, 59, 1217-1232.

Zhang, J., \& Liu, C. L. (2002). Riverine composition and estuarine geochemistry of particulate metals in China: weathering features, anthropogenic impact and chemical fluxes. Estuarine, Coastal and Shelf Science, 54, 1051-1070.

Zhang, W., Feng, H., Chang, J., Qu, J., Xie, H., \& Yu, L. (2009). Heavy metal contamination in surface sediments of Yangtze River intertidal zone: An assessment from different indexes. Environmental Pollution, 157, 1533-1543. 


\section{List of Figures}

Fig. 1 Location map of the study area

Fig. 2 The mean concentrations of major and trace elements $(n=22)$ in surface sediments of Buckingham Canal, south India (SBC-South Buckingham Canal; NBC-North Buckingham Canal)

Fig. 3a-m The distribution Pattern of total trace metals (Fe, Mn, $\mathrm{P}, \mathrm{Sr}, \mathrm{V}, \mathrm{Ni}, \mathrm{Ba}, \mathrm{Cr}, \mathrm{Cu}, \mathrm{Zn}, \mathrm{Pb}$, Sn and Mo) in surface sediments of Buckingham canal, south India.

Fig. 4 Results of factor analysis in surface sediments of Buckingham Canal south India $(n=22)$

Fig. 5 Dendrogram based complete linkage method for Buickingham Canal, south India ( $=22$ )

Fig. 6 Enrichment factor $(\mathrm{EFs})$ for surface sediments of Buckingham Canal, south India $(\mathrm{n}=22)$

Fig. 7 Contamination factor (CFs) for the trace metals in surface sediments of Buckingham Canal south India $(\mathrm{n}=22)$

Fig. 8a, b Biological effects of TTMs (a.South Buckingham Canal, b. North Buckingham Canal). 


\section{List of Tables}

Table 1 Statistical results of analytical values (minimum, maximum, average, standard deviation) of the surface sediments of Buckingham Canal, south India $(\mathrm{n}=22)$

Table 2 Comparison of total trace metals in sediments of present study with channel sediments around the world and lakes, coastal areas, rivers in and around the study area.

Table 3 Correlation matrix (r) of trace elements in surface sediments of Buckingham Canal, south India $(\mathrm{n}=22)$

Table 4 Geo Accumulation Index ( $\mathrm{I}_{\text {geo }}$ ) for surface sediments of Buckingham Canal, south India (n $=22)$

Table 5 Guideline values and biological effects of the trace metals in surface sediments of Buckingham Canal, south India 